\title{
Recent Advances in the Surface Functionalization of Nanomaterials for Antimicrobial Applications
}

\author{
Shahin Shah Khan (D), Irfan Ullah (D), Sadeeq Ullah, Ruipeng An, Haijun Xu, Kaili Nie, Chaoyong Liu \\ and Luo Liu*(D)
}

check for updates

Citation: Khan, S.S.; Ullah, I.; Ullah, S.; An, R.; Xu, H.; Nie, K.; Liu, C.; Liu L. Recent Advances in the Surface Functionalization of Nanomaterials for Antimicrobial Applications. Materials 2021, 14, 6932. https:// doi.org/10.3390/ma14226932

Academic Editor: Anton Nikiforov

Received: 30 September 2021 Accepted: 10 November 2021 Published: 16 November 2021

Publisher's Note: MDPI stays neutral with regard to jurisdictional claims in published maps and institutional affiliations.

Copyright: (c) 2021 by the authors. Licensee MDPI, Basel, Switzerland. This article is an open access article distributed under the terms and conditions of the Creative Commons Attribution (CC BY) license (https:/ / creativecommons.org/licenses/by/ $4.0 /)$.
College of Life Science and Technology, Beijing University of Chemical Technology, Beijing 100029, China; khan@mail.buct.edu.cn (S.S.K.); irfan@mail.buct.edu.cn (I.U.); 2018420012@mail.buct.edu.cn (S.U.); 18613228193@163.com (R.A.); hjxu@mail.buct.edu.cn (H.X.); niekl@mail.buct.edu.cn (K.N.); chaoyongliu@mail.buct.edu.cn (C.L.)

* Correspondence: liuluo@mail.buct.edu.cn

\begin{abstract}
Innovations in nanotechnology have had an immense impact on medicine, such as in drug delivery, tissue engineering, and medical devices that combat different pathogens. The pathogens that may cause biofilm-associated nosocomial diseases are multidrug-resistant (MDR) bacteria, such as Escherichia coli (E. coli), Pseudomonas aeruginosa (P. aeruginosa), Staphylococcus aureus (S. aureus), including both Gram-positive and Gram-negative bacterial species. About $65-80 \%$ of infections are caused by biofilm-associated pathogens creating a move in the international community toward developing antimicrobial therapies to eliminate such pathogenic infections. Several nanomaterials (NMs) have been discovered and significantly employed in various antipathogenic therapies. These NMs have unique properties of singlet oxygen production, high absorption of near-infrared irradiation, and reasonable conversion of light to heat. In this review, functionalized NPs that combat different pathogenic infections are introduced. This review highlights NMs that combat infections caused by multidrug-resistant (MDR) and other pathogenic microorganisms. It also highlights the biomedical application of NPs with regard to antipathogenic activities.
\end{abstract}

Keywords: nanoparticles; surface functionalization; NIR; MDR; antibacterial activities; nosocomial diseases

\section{Introduction}

The use of medical devices in the field of medicine for therapeutic and diagnostic purposes has high importance. However, the risks associated with their usage are not negligible, particularly when these devices are intended to be inserted inside the body for long periods of time. The most important associated problems are colonization of bacteria on medical devices after surgeries, having a significant impact on patient health and the costs associated with the treatment of infectious disease. These barriers are commonly connected with bacteria that cause contamination of surgical wounds during surgery or during the time of hospitalization, which may result in a nosocomial infection [1]. So, these infections are extremely difficult to handle as bacteria (e.g., methicillin-resistant Staphylococcus aureus (MRSA) and vancomycin-resistant Enterococcus (VRE)) are more resistant to classical antibiotic therapies; particularly, medical devices, when colonized by bacteria, create a biofilm that is more dangerous for patient health [2]. Once bacteria make a coat on a hard surface, they can protect themselves by producing an extracellular matrix rich in exopolysaccharides. The bacteria colonization of the surface of medical devices or hard surfaces confer to biofilm a surface that provides a polysaccharide shelter that is resistant to our immune system [3].

The slow growth rate of bacteria and the biofilm microenvironment act together to facilitate the development of antibiotic resistance [4]. Furthermore, these infections are mainly caused by multidrug-resistant (MDR) bacteria, P. aeruginosa, E. coli, S. aureus, MRSA, VRE, Acinetobacter baumanii, and coagulase-negative Staphylococcus, which infect more 
than two million people annually in the United States, resulting in a significant loss of life and limb, with treatment requiring prolonged and costly therapeutic regimens [5]. The national institute of health (NIH) revealed that $65-80 \%$ of the infections are due to biofilm-associated pathogens [6]. The high risk regarding biofilm-associated nosocomial infections requires an international scientific movement to develop antimicrobial therapies to eliminate these infections [7]. For this purpose, nanotechnology is an emerging field in which different nanomaterials (NMs) act by surface plasmon resonance. Surface plasmon resonance is a powerful technique that retrieves information on the optical properties of NMs by striking incident light on its structure, which fluctuates the electrons at a specific resonance frequency and acts as a sensor to the transduced absorption band in the UV spectrum [8,9]. Furthermore, NPs can absorb near-infrared radiation (NIR), convert light to heat, and generate radicals, which highlight their therapeutic application against different pathogens [10]. These NPs are generally classified based on morphology, dimensionality, and chemical nature, and are categorized as isometric and inhomogeneous or dispersed and agglomerate [11].

This review highlights surface functionalization regarding the interaction of NPs with microbial cells, particularly how the unique characteristics of plasmon-based NPs influence their uptake pathway, NPs intracellular location and translocation, cytotoxicity, and biological application at the cellular level. The current knowledge of the physicochemical properties of NPs in light of antimicrobial activities will alleviate the effects of nosocomial diseases and combat these pathogens with their synergistic effects. These NPs combat microbial infection by mechanisms of reactive oxygen species (ROS)-based photodynamic therapy (PDT) and hypothermia-based photothermal therapy (PTT). PDT involves combating pathogenic bacteria via ROS, including superoxide anion $\left(\mathrm{O}_{2}{ }^{-}\right)$, hydrogen peroxide $\left(\mathrm{H}_{2} \mathrm{O}_{2}\right)$, singlet oxygen $\left({ }^{1} \mathrm{O}_{2}\right)$, and hydroxyl radical $(\cdot \mathrm{OH})$ [12]. It is also widely accepted that ROS can bind and damage the cell membrane and cell wall, thus destroying the defense system of pathogenic microorganisms $[13,14]$. The PTT mechanism of NPs involves the conversion of light into heat, which can kill pathogens by absorbing light (NIR) and converting it into heat $[15,16]$. Most importantly, we must construct safe and engineered NMs against different microbial infections and explore their biomedical applications.

\section{Surface Functionalization and Characteristics of NPs for Antimicrobial Activities}

To impart antimicrobial activity to NMs, there are three main different strategies. The first is to functionalize the NMs or polymers using antimicrobial agents such as quaternary ammonium compounds (QACs) $[17,18]$ through a mechanism of contact killing. This strategy has been used extensively for the improvement in the microbicidal effectiveness of various surfaces. In particular, QACs are mostly used as disinfectants and microbicidal agents, having long alkyl chains to induce strong toxicity against amoeba and fungi, as well as to envelop viruses $[19,20]$. The second is to fabricate nanocomposites by adding filler such as metal-based NMs, e.g., Ag NPs. Four steps are necessary to create the antimicrobial activity of Ag NPs: (1) approach the surface of bacteria; (2) disrupt the cell wall and membrane; (3) produce free radicals and ROS, which exerts toxicity and oxidative stress effects; and (4) modulate signal transduction pathways. The third is the encapsulation of antimicrobial drugs or biomolecules, e.g., gentamicin. These functionalized NMs have strong toxicity against different infections caused by MDR bacteria, fungi, and viruses [21,22].

Different techniques are used for surface functionalization of carbon materials, i.e., oxidative process and non-destructive surface modification. In oxidative processes, the oxidized NMs further act as a precursor for chemical modifications such as silanization, polymer grafting, esterification, alkylation, arylation, etc., while non-destructive surface modifications are achieved by polymers wrapping, surfactant adsorption, and encapsulating processes $[23,24]$. Furthermore, the main aims of NPs surface functionalization are to tackle toxicity, the clearance of immune responses, and attachment of more complex and specific ligands to enhance efficacy and specificity for purposes such as antipathogenic activities through NPs [25]. 
Recently, the structural and behavioral changes of microorganisms have rapidly increased. The appearance of resistant bacteria by enhancing antibiotic adaptation is a significant concern for public health; thus, many efforts are needed to promote the efficiency and efficacy of antimicrobial substances. Surface functionalization of antimicrobial NPs can improve their efficiency, and various studies have shown their potential for use against resistant bacteria [26]; it also reduces the tendency to agglomerate carbon materials and increase the interfacial adhesion of carbon-polymer through covalent or ionic bonds [27].

For the use of NMs in biomedical applications, two main characteristics must be considered: toxicity and cellular uptake [28]. In nanotechnology, biocompatibility is one of the important characteristics of NPs for biomedical purposes, which describes the properties of materials being compatible with living tissues. The most important goal is to internalize NPs to targeted cells/tissues compared to non-targeted cells and to minimize the toxicity of the NPs into cells $[29,30]$. NPs also have unique physical and chemical properties due to their high surface area and nanoscale size [31].

\section{Antimicrobial Activities of Nanomaterials}

Antimicrobial resistance (AMR) occurs when bacteria, viruses, fungi, and parasites change over time and no longer respond to medicines, making infections harder to treat and increasing the risk of disease spread, severe illness, and death. It was implicated that more than $70 \%$ of micro-organisms causing infections are resistant to one or more antimicrobial agents used as treatment to eradicate infections [32]. Considering the current situation worldwide, there is concern about controlling MDR pathogens for infectious diseases preventions. Additionally, the significant prevalence of cross-contaminations and drug overuses, which may lead to biofilm development, may cause nosocomial disease that shows more resistance to standard therapies [33]. There are several mechanisms through which antibiotic resistance is achieved in bacteria, i.e., drug penetration prevention into a cell, antibiotics target changes, enzymatic inactivation of antibiotics, and active excretion of an antibiotic from a cell [34]. Some pathogenic fungal strains are also involved in biofilm formation and are more dangerous than bacterial biofilm. These fungal strains are likely yeast and filamentous fungi, and the most studied model is Candida albicans (C. albicans). There are also other species (spp.), such as Histoplasma capsulatum, Paracoccidioides, Trichophyton, C. glabrata, C. tropicalis, C. parapsilosis, Cryptococcus spp., Malassezia spp., Trichosporon spp., Fusarium spp., Scedosporium spp., Lomentospora prolificans, and Coccidioides spp. Table 1 reveals the NMs that have activities against different MDR pathogens, antibacterials, antifungals, and antivirals that combat the biofilm-associated nosocomial pathogens mentioned above [35-73].

Table 1. Activities of different NPs against MDR-pathogens, antibacterial, antifungal and antiviral.

\begin{tabular}{|c|c|c|c|}
\hline NPs & Activity & Targeted Pathogen & Refs. \\
\hline Au NPs & & $\begin{array}{l}\text { Methicillin-resistant S. Aureus, various groups of MDR (multidrug-resistant) } \\
\text { Gram-positive (MRSA, MRSE, and MLSB), and Gram-negative } \\
\text { (extended-spectrum betalactamase (ESBL), AmpC, and CR) pathogens }\end{array}$ & {$[32,74]$} \\
\hline Ag NPs & MDR pathogens & $\begin{array}{l}\text { S. epidermidis, MRSA, VRE, ESBL-producing organisms, MDR E. coli, P. } \\
\text { aeruginosa, K. pneumoniae, carbapenem- and polymyxin B-resistant A. baumannii, } \\
\text { Salmonella typhi (S. typhi), and S. aureus Carbapenem-resistant P. aeruginosa and } \\
\text { carbapenem-resistant Enterobacteriaceae (CRE) }\end{array}$ & {$[32,75-79]$} \\
\hline Cu NPs & & S. aureus, E. faecalis, E. coli, and P. aeruginosa, K. quasipneumoniae and Enterobacter sp. & {$[80,81]$} \\
\hline Se NPs & & S. aureus, P. aeruginosa, and E. coli & [82] \\
\hline
\end{tabular}


Table 1. Cont

\begin{tabular}{|c|c|c|c|}
\hline NPs & Activity & Targeted Pathogen & Refs. \\
\hline Al NPs & \multirow{3}{*}{ MDR pathogens } & MDR K. pneumoniae & [83] \\
\hline $\begin{array}{l}\text { Metal oxide NPs } \\
\mathrm{ZnO}_{2}-\mathrm{NPs} \\
\mathrm{ZnO} \mathrm{NPs} \\
\mathrm{TiO}_{2} \mathrm{NPs}\end{array}$ & & MDR E. coli, S. aureus & {$[84,85]$} \\
\hline $\mathrm{CeO}_{2} \mathrm{NPs}$ & & K. pneumoniae & [86] \\
\hline \multicolumn{4}{|c|}{ Antibacterial activities of different NPs } \\
\hline Ag NPs & \multirow{11}{*}{ Antibacterial } & $\begin{array}{l}\text { E. coli, B. subtilis, S. aureus, methicillin-resistant coagulase-negative Staphylococci, } \\
\text { VRE faecium, ESBL-positive K. Pneumonia, S. typhi, Vibrio cholera }\end{array}$ & {$[36-39]$} \\
\hline $\mathrm{Au}$ NPs & & MRSA, VRE-faecium, E. coli, P. aeruginosa & {$[40]$} \\
\hline $\mathrm{TiO}_{2} \mathrm{NPs}$ & & $\begin{array}{l}\text { E. coli } 0157: H 7, \text { S. aureus, } \\
\text { L. monocytogenes S. enteritidis, } \\
\text { P. fluorescens }\end{array}$ & [41] \\
\hline ZnO NPs & & $\begin{array}{l}\text { E. coli 0157:H7, B. subtilis, P. fluorescens, } \\
\text { L. monocytogenes, S. enteritidis, S. aureus, } \\
\text { S. typhimurium }\end{array}$ & {$[42,43]$} \\
\hline $\mathrm{CuONPs}$ & & $\begin{array}{l}\text { B. subtilis, L. monocytogenes, S. aureus, } \\
\text { E. coli }\end{array}$ & {$[44]$} \\
\hline HSA-GO-Pd & & E. coli & [87] \\
\hline $\mathrm{MgO}$ NPs & & B. subtilis, E. coli, S. aureus, B. megaterium & {$[45,46]$} \\
\hline $\mathrm{CaO}$ NPs & & S. aureus, S. epidermidis, E. coli, S. mutans & [47] \\
\hline $\mathrm{Al}_{2} \mathrm{O}_{3} \mathrm{NPs}$ & & $\begin{array}{l}\text { E. coli, } P \text {. aeruginosa, S. aureus, B. subtilis, } \\
\text { K. aerogenes, P. desmolyticum }\end{array}$ & {$[48-50]$} \\
\hline $\mathrm{SiO}_{2} \mathrm{NPs}$ & & E. coli, S. mutans, B. subtilis & {$[51]$} \\
\hline Clay NPs & & $\begin{array}{l}\text { E. coli, E. faecalis, S. aureus, } \\
\text { P. aeruginosa }\end{array}$ & [52] \\
\hline \multicolumn{4}{|c|}{ Antifungal activities of different NPs } \\
\hline Ag NPs & \multirow{9}{*}{ Antifungal } & C. albicans, T. mentagrophyts, B. sorokiniana, M. grisea & [53-55] \\
\hline $\mathrm{ZnO} \mathrm{NPs}$ & & $\begin{array}{l}\text { B. cinerea, P. expansum, A. flavus, S. cerevisiae, C. albicans, R. stolonifera, } F \text {. } \\
\text { oxysporum, Mucor, A. fumigatus, A. niger, and F. solani }\end{array}$ & {$[50,54-56]$} \\
\hline $\mathrm{TiO}_{2}$ NPs & & $\begin{array}{l}\text { Candida. spp. P. Expansum, A. niger spp. } \\
\text { P. oxalicum }\end{array}$ & {$[57,58]$} \\
\hline $\mathrm{CuONPs}$ & & $\begin{array}{l}\text { A. niger, Rhizopus oryzae, A. flavus, } \\
\text { Cladosporium carrionii, Mucor, } \\
\text { S. cerevisiae, } P \text {. notatum, C. albicans }\end{array}$ & {$[59,60]$} \\
\hline $\mathrm{MgO}$ NPs & & $\begin{array}{l}\text { Saccharomyces cerevisiae, C. albicans, } \\
\text { A. niger, R. stolonifer, Fusarium oxysporumf. sp. lycopersici }\end{array}$ & {$[61,62]$} \\
\hline $\mathrm{CaO}$ NPs & & S. cerevisiae, C. albicans, A. Niger, R. stolonifer, C. brevisporum & {$[61,63]$} \\
\hline $\mathrm{Au}$ NPs & & Puccinia graminis tritci, A. flavus, A. niger C. albicans & {$[64,65]$} \\
\hline $\mathrm{SiO}_{2} \mathrm{NPs}$ & & Candida. spp., Dermatophytes spp., A. niger, and S. racemosum & {$[66,67]$} \\
\hline $\mathrm{Al}_{2} \mathrm{O}_{3} \mathrm{NPs}$ & & Candida. spp., S. quadricauda, A. niger, A. flavus, Fusarium spp., and Alternaria spp. & {$[66,68]$} \\
\hline \multicolumn{4}{|c|}{ Antiviral activities of different NPs } \\
\hline $\mathrm{Au}$ NPs & \multirow{4}{*}{ Antiviral } & HIV virus, Influenza virus, Herpes Simplex virus (HSV-1) & [69-71] \\
\hline $\begin{array}{l}\mathrm{Ag} \mathrm{NPs} \\
\mathrm{Ag}_{2} \mathrm{O} / \mathrm{AgO}-\mathrm{NPs}\end{array}$ & & $\begin{array}{l}\text { HIV-1, Influenza virus, Herpes Simplex virus, Respiratory syncytial virus, } \\
\text { Monkey pox virus, SARS-CoV-2 }\end{array}$ & {$[69-72,88,89]$} \\
\hline $\mathrm{TiO}_{2} \mathrm{NPs}$ & & Inactivates bacteriophages & {$[50]$} \\
\hline CuI NPs & & Influenza A virus, feline Calicivirus (FCV) & {$[73]$} \\
\hline
\end{tabular}

In this regard, developing non-conventional antimicrobial agents to prevent the aforementioned causes is under study. The rapid development of nanoscience and nanotechnology has shown promising potential for developing novel biocidal agents that would integrate with a biomaterial to prevent bacterial colonization and biofilm formation [33,90]. 
Metals with inherent antimicrobial properties such as silver, copper, and zinc, on the nanoscale, constitute a special class of antimicrobials that have a broad-spectrum antimicrobial nature and pose minimum toxicity to humans. Furthermore, a wide range of metals has antimicrobial activity, e.g., $\mathrm{Ag}, \mathrm{Al}, \mathrm{As}, \mathrm{Cd}, \mathrm{Co}, \mathrm{Cr}, \mathrm{Cu}, \mathrm{Fe}, \mathrm{Ga}, \mathrm{Hg}$, $\mathrm{Mo}, \mathrm{Mn}$, $\mathrm{Ni}, \mathrm{Pb}, \mathrm{Sb}, \mathrm{Te}$, and $\mathrm{Zn}[33,35,74,76-86]$. These NMs have vast antipathogenic activities and are used to eradicate such pathogens that have strong resistance against normal therapies. These NPs tackle pathogens by having biocompatibility, biodegradability, reactive oxygen species (ROS) production, high absorption of NIR irradiation, and photodynamic and photothermal-conversion mechanisms, which show high performance in antipathogenic therapies.

Understanding the main role of nanotechnology and its biomedical applications, in addition to antipathogenic therapies, is also promising; the most remarkable roles of NMs are in stem-cell-based therapies, neurodegenerative diseases, anticancer treatment, and gene delivery, which are currently being researched [91]. However, there are also a few drawbacks to be considered during the use of NPs for in vivo models. Most NPs disturb cell viability, alter mitochondrial functions, increase oxidative stresses, and alter tight junction protein expression of the blood barriers [92]. Hence, novel biomaterials that inhibit microbial growth and have low toxicity would be of great significance [33].

\section{Outlook and Further Perspectives}

Many scientists have reported several studies on NPs and their biomedical applications according to current demands. The biomedical application of NPs remains the most attractive aspect for scientists to improve clinical outcomes. The targeted drug and gene delivery diagnostic algorithmic treatment approaches improve efficacy while reducing side effects. However, the promising role of nanotechnology in combating different pathogens is more reliable and technical compared to standard antibiotics therapies. Metal NPs, owing to their unique adaptable physical and chemical properties, have been investigated widely in biomedical research.

Metal NPs have a unique interaction with light, which provides competent means for tracking nano-complex therapeutics carriers within the body, allowing more efficient therapies with low adverse effects compared to current conventional therapies. Interestingly, due to their high drug payload, surface chemistry, electrostatic charges, and photothermal behavior, metal NPs enhance therapeutics' antimicrobial drug efficacy.

In this review, we discuss the promising role of functionalizing NPs with an antimicrobial agent, adding filler on its surface or encapsulating the antimicrobial agent, which allows for combating activities against different pathogens such as MDR, bacterial, fungal, and viral infections. Conclusively, based on the current literature on pre-clinical trials, plasmon-based metal NPs and their combination approaches are good prospects in microbial infectious therapies; for instance, biocompatibility, generation of singlet oxygen, and photothermal conversion properties of plasmon-based metal NPs are useful, and helpful in anticancer therapies. Further extensive research on NPs into their long-term toxicity is essential for successful clinical use in biomedical applications. We also think that the development of simple and low-cost inorganic antimicrobial agents such as NPs as alternatives for traditional antimicrobial agents might be promising for the future of the pharmaceutical, food, and medical industries.

Author Contributions: S.S.K.; Conceptualization, writing-original draft preparation, I.U.; writingreview and editing, S.U.; validation, R.A.; formal analysis, H.X.; Conceptualization, K.N.; investigation, C.L.; project administration, L.L.; supervision, funding acquisition. All authors have read and agreed to the published version of the manuscript.

Funding: This study was funded by National Natural Science Foundation of China (grant number 52073022).

Institutional Review Board Statement: Not applicable. 
Informed Consent Statement: Not applicable.

Data Availability Statement: The data presented in this study are avalible on request from the corresponding author.

Conflicts of Interest: The authors declare no conflict of interest.

\section{References}

1. Schierholz, J.M.; Beuth, J. Implant infections: A haven for opportunistic bacteria. J. Hosp. Infect. 2001, 49, 87-93. [CrossRef]

2. Dupont, H. The empiric treatment of nosocomial intra-abdominal infections. Int. J. Infect. Dis. 2007, 11, S1-S6. [CrossRef]

3. Pérez-Köhler, B.; Bayon, Y.; Bellón, J.M. Mesh infection and hernia repair: A review. Surg. Infect. 2016, 17, 124-137. [CrossRef]

4. Olsen, I. Biofilm-specific antibiotic tolerance and resistance. Eur. J. Clin. Microbiol. Infect. Dis. 2015, 34, 877-886. [CrossRef]

5. De Miguel, I.; Prieto, I.; Albornoz, A.; Sanz, V.; Weis, C.; Turon, P.; Quidant, R. Plasmon-based biofilm inhibition on surgical implants. Nano Lett. 2019, 19, 2524-2529. [CrossRef] [PubMed]

6. Jamal, M.; Ahmad, W.; Andleeb, S.; Jalil, F.; Imran, M.; Nawaz, M.A.; Hussain, T.; Ali, M.; Rafiq, M.; Kamil, M.A. Bacterial biofilm and associated infections. J. Chin. Med. Assoc. 2018, 81, 7-11. [CrossRef] [PubMed]

7. Del Pozo, J.L.; Patel, R. The challenge of treating biofilm-associated bacterial infections. Clin. Pharmacol. Ther. 2007, 82, 204-209. [CrossRef] [PubMed]

8. Ghosh, S.K.; Pal, T. Interparticle coupling effect on the surface plasmon resonance of gold nanoparticles: From theory to applications. Chem. Rev. 2007, 107, 4797-4862. [CrossRef]

9. Olson, J.; Dominguez-Medina, S.; Hoggard, A.; Wang, L.Y.; Chang, W.S.; Link, S. Optical characterization of single plasmonic nanoparticles. Chem. Soc. Rev. 2015, 44, 40-57. [CrossRef] [PubMed]

10. Jaque, D.; Maestro, L.M.; del Rosal, B.; Haro-Gonzalez, P.; Benayas, A.; Plaza, J.L.; Rodríguez, E.M.; Solé, J.G. Nanoparticles for photothermal therapies. Nanoscale 2014, 6, 9494-9530. [CrossRef]

11. Saleh, T.A. Nanomaterials: Classification, properties, and environmental toxicities. Environ. Technol. Innov. 2020, 1-16. [CrossRef]

12. Ren, Y.; Liu, H.; Liu, X.; Zheng, Y.; Li, Z.; Li, C.; Yeung, K.W.K.; Zhu, S.; Liang, Y.; Cui, Z.; et al. Photoresponsive materials for antibacterial applications. Cell Rep. Phys. Sci. 2020, 1, 1-30. [CrossRef]

13. Wei, T.; Yu, Q.; Chen, H. Responsive and synergistic antibacterial coatings: Fighting against bacteria in a smart and effective way. Adv. Healthc. Mater. 2019, 8. [CrossRef]

14. Li, J.; Liu, X.; Tan, L.; Liang, Y.; Cui, Z.; Yang, X.; Zhu, S.; Li, Z.; Zheng, Y.; Yeung, K.W.K.; et al. Light-activated rapid disinfection by accelerated charge transfer in red phosphorus/ZnO heterointerface. Smal. Meth. 2019, 3. [CrossRef]

15. Chen, B.Q.; Kankala, R.K.; Zhang, Y.; Xiang, S.T.; Tang, H.X.; Wang, Q.; Yang, D.Y.; Wang, S.B.; Zhang, Y.S.; Liu, G.; et al. Gambogic acid augments black phosphorus quantum dots (BPQDs)-based synergistic chemo-photothermal therapy through downregulating heat shock protein expression. Chem. Eng. Sci. 2020, 390, 5302-5318. [CrossRef]

16. Xu, J.W.; Yao, K.; Xu, Z.K. Nanomaterials with a photothermal effect for antibacterial activities: An overview. Nanoscale 2019, 11, 8680-8691. [CrossRef]

17. Chaker, A.; Boufi, S. Cationic nanofibrillar cellulose with high antibacterial properties. Carbohydr. Polym. 2015, 131, 224-232. [CrossRef]

18. Makvandi, P.; Jamaledin, R.; Jabbari, M.; Nikfarjam, N.; Borzacchiello, A. Antibacterial quaternary ammonium compounds in dental materials: A systematic review. Dent. Mater. 2018, 34, 851-867. [CrossRef]

19. Makvandi, P.; Gu, J.T.; Zare, E.N.; Ashtari, B.; Moeini, A.; Tay, F.R.; Niu, L.N. Polymeric and inorganic nanoscopical antimicrobial fillers in dentistry. Acta Biomater. 2020, 101, 69-101. [CrossRef]

20. Makvandi, P.; Pollini, M.; Gallo, A.L.; Maffezzoli, A.; Esposito Corcione, C.; Montagna, F.; Paladini, F.; Jamaledin, R. Antimicrobial modified hydroxyapatite composite dental bite by stereolithography. Polym. Adv. Technol. 2017, 29, 364-371. [CrossRef]

21. Dakal, T.C.; Kumar, A.; Majumdar, R.S.; Yadav, V. Mechanistic basis of antimicrobial actions of silver nanoparticles. Front. Microbiol. 2016, 7, 1831. [CrossRef]

22. Delfi, M.; Ghomi, M.; Zarrabi, A.; Mohammadinejad, R.; Taraghdari, Z.B.; Ashrafizadeh, M.; Zare, E.N.; Agarwal, T.; Padil, V.V.; Mokhtari, B.; et al. Functionalization of polymers and nanomaterials for biomedical applications: Antimicrobial platforms and drug carriers. Prosthe 2020, 2, 117-139. [CrossRef]

23. Sham, M.L.; Kim, J.K. Surface functionalities of multi-wall carbon nanotubes after UV/Ozone and TETA treatments. Carbon 2006, 44, 768-777. [CrossRef]

24. Kostarelos, K.; Lacerda, L.; Pastorin, G.; Wu, W.; Wieckowski, S.; Luangsivilay, J.; Godefroy, S.; Pantarotto, D.; Briand, J.P.; Muller, S.; et al. Cellular uptake of functionalized carbon nanotubes is independent of functional group and cell type. Nat. Nanotechnol. 2007, 2, 108-113. [CrossRef]

25. Sanità, G.; Carrese, B.; Lamberti, A. Nanoparticle surface functionalization: How to improve biocompatibility and cellular internalization. Front. Mol. Biosci. 2020, 7, 381. [CrossRef]

26. Bahrami, A.; Delshadi, R.; Jafari, S.M. Active delivery of antimicrobial nanoparticles into microbial cells through surface functionalization strategies. Trends Food Sci. Technol. 2020, 99, 217-228. [CrossRef]

27. Nayak, L.; Rahaman, M.; Giri, R. Surface modification/functionalization of carbon materials by different techniques: An overview. Carbon-Contain. Polym. Compos. 2019, 65-98. [CrossRef] 
28. Santos-Rasera, J.R.; Neto, A.S.A.; Monteiro, R.T.R.; van Gestel, C.A.; de Carvalho, H.W.P. Toxicity, bioaccumulation and biotransformation of Cu oxide nanoparticles in Daphnia magna. Environ. Sci. Nano 2019, 6, 2897-2906. [CrossRef]

29. Liu, T.; Bai, R.; Zhou, H.; Wang, R.; Liu, J.; Zhao, Y.; Chen, C. The effect of size and surface ligands of iron oxide nanoparticles on blood compatibility. RSC Adv. 2020, 10, 7559-7569. [CrossRef]

30. Bharadwaj, A. An Overview on Biomaterials and Its Applications in Medical Science. Mater. Sci. Eng. 2021, 1116, 012178. [CrossRef]

31. Khan, I.; Saeed, K.; Khan, I. Nanoparticles: Properties, applications and toxicities. Arab. J. Chem. 2019, 12, 908-931. [CrossRef]

32. Malarkodi, C.; Rajeshkumar, S.; Paulkumar, K.; Vanaja, M.; Gnanajobitha, G.; Annadurai, G. Biosynthesis and antimicrobial activity of semiconductor nanoparticles against oral pathogens. Bioinorg. Chem. Appl. 2014, 1-10. [CrossRef] [PubMed]

33. Agnihotri, S.; Dhiman, N.K. Development of nano-antimicrobial bio=materials for biomedical applications. Adv. Bio. Mat. For. Biomed. Appl. 2017, 66, 479-545. [CrossRef]

34. Ahamed, M.N.; Sankar, S.; Kashif, P.M.; Basha, S.H.; Sastry, T.P. Evaluation of biomaterial containing regenerated cellulose and chitosan incorporated with silver nanoparticles. Int. J. Biol. 2015, 72, 680-686. [CrossRef] [PubMed]

35. Costa-Orlandi, C.B.; Sardi, J.C.; Pitangui, N.S.; de Oliveira, H.C.; Scorzoni, L.; Galeane, M.C.; Medina-Alarcón, K.P.; Melo, W.C.; Marcelino, M.Y.; Braz, J.D.; et al. Fungal biofilms and polymicrobial diseases. J. Fungi 2017, 3, 22. [CrossRef]

36. Feng, Q.L.; Wu, J.; Chen, G.Q.; Cui, F.Z.; Kim, T.N.; Kim, J.O. A mechanistic study of the antibacterial effect of silver ions on Escherichia coli and Staphylococcus aureus. J. Biomed. Mater. Res. 2000, 52, 662-668. [CrossRef]

37. Jung, W.K.; Koo, H.C.; Kim, K.W.; Shin, S.; Kim, S.H.; Park, Y.H. Antibacterial activity and mechanism of action of the silver ion in Staphylococcus aureus and Escherichia coli. Appl. Environ. Microbiol. 2008, 74, 2171-2178. [CrossRef]

38. Nanda, A.; Saravanan, M. Biosynthesis of silver nanoparticles from Staphylococcus aureus and its antimicrobial activity against MRSA and MRSE. Nanomed. Nanotechnol. Biol. Med. 2009, 5, 452-456. [CrossRef]

39. Kim, J.S.; Kuk, E.; Yu, K.N.; Kim, J.H.; Park, S.J.; Lee, H.J.; Kim, S.H.; Park, Y.K.; Park, Y.H.; Hwang, C.Y.; et al. Antimicrobial effects of silver nanoparticles. Nanomed. Nanotechnol. Biol. Med. 2007, 3, 95-101. [CrossRef]

40. Gil-Tomás, J.; Tubby, S.; Parkin, I.P.; Narband, N.; Dekker, L.; Nair, S.P.; Wilson, M.; Street, C. Lethal photosensitisation of Staphylococcus aureus using a toluidine blue O-tiopronin-gold nanoparticle conjugate. J. Mater. Chem. 2007, 17, 3739-3746. [CrossRef]

41. MubarakAli, D.; Thajuddin, N.; Jeganathan, K.; Gunasekaran, M. Plant extract mediated synthesis of silver and gold nanoparticles and its antibacterial activity against clinically isolated pathogens. Colloids Surf. B Biointerfaces 2011, 85, 360-365. [CrossRef] [PubMed]

42. Matsunaga, T.; Tomoda, R.; Nakajima, T.; Nakamura, N.O.; Komine, T. Continuous-sterilization system that uses photo semiconductor powders. Appl. Environ. Microbiol. 1988, 54, 1330-1333. [CrossRef] [PubMed]

43. Othman, S.H.; Abd, S.N.R.; Zainal, N.; Kadir, B.R.; Talib, R.A. Antimicrobial activity of $\mathrm{TiO}_{2}$ nanoparticle-coated film for potential food packaging applications. Int. J. Photoenergy 2014, 1-6. [CrossRef]

44. Ren, G.; Hu, D.; Cheng, E.W.; Vargas-Reus, M.A.; Reip, P.; Allaker, R.P. Characterization of copper oxide nanoparticles for antimicrobial applications. Int. J. Antimicrob. Agents 2009, 33, 587-590. [CrossRef] [PubMed]

45. Richards, R.; Li, W.; Decker, S.; Davidson, C.; Koper, O.; Zaikovski, V.; Volodin, A.; Rieker, T.; Klabunde, K.J. Consolidation of metal oxide nanocrystals. Reactive pellets with controllable pore structure that represent a new family of porous, inorganic materials. J. Am. Chem. Soc. 2000, 122, 4921-4925. [CrossRef]

46. Krishnamoorthy, K.; Manivannan, G.; Kim, S.J.; Jeyasubramanian, K.; Premanathan, M. Antibacterial activity of MgO nanoparticles based on lipid peroxidation by oxygen vacancy. J. Nanoparticle Res. 2012, 14, 1-10. [CrossRef]

47. Roy, A.; Gauri, S.S.; Bhattacharya, M.; Bhattacharya, J. Antimicrobial activity of CaO nanoparticles. J. Biomed. Nanotech. 2013, 9 , 1570-1578. [CrossRef] [PubMed]

48. Prashanth, P.A.; Raveendra, R.S.; Hari, K.R.; Ananda, S.; Bhagya, N.P.; Nagabhushana, B.M.; Lingaraju, K.; Raja, N.H. Synthesis, characterizations, antibacterial and photoluminescence studies of solution combustion-derived $\alpha-\mathrm{Al}_{2} \mathrm{O}_{3}$ nanoparticles. J. Asian Ceram. Soc. 2015, 3, 345-351. [CrossRef]

49. Jastrzębska, A.M.; Radziun, E.; Rosłon, M.; Kunicki, A.R.; Olszyna, A.R.; Dudkiewicz-Wilczyńska, J.; Anuszewska, E.; Karwowska, E. In vitro assessment of antibacterial properties and cytotoxicity of $\mathrm{Al}_{2} \mathrm{O}_{3}-\mathrm{Ag}$ nanopowders. Adv. Appl. Ceram. 2011, 110, 353-359. [CrossRef]

50. Khezerlou, A.; Alizadeh-Sani, M.; Azizi-Lalabadi, M.; Ehsani, A. Nanoparticles and their antimicrobial properties against pathogens including bacteria, fungi, parasites and viruses. Microb. Pathog. 2018, 123, 505-526. [CrossRef] [PubMed]

51. Silvestry-Rodriguez, N.; Sicairos-Ruelas, E.E.; Gerba, C.P.; Bright, K.R. Silver as a disinfectant. Rev. Environ. Contam. Toxicol. 2007, 23-45. [CrossRef]

52. Bagchi, B.; Kar, S.; Dey, S.K.; Bhandary, S.; Roy, D.; Mukhopadhyay, T.K.; Das, S.; Nandy, P. In situ synthesis and antibacterial activity of copper nanoparticle loaded natural montmorillonite clay based on contact inhibition and ion release. Colloids Surf. $B$ Biointerfaces 2013, 108, 358-365. [CrossRef] [PubMed]

53. Panáček, A.; Kolář, M.; Večeřová, R.; Prucek, R.; Soukupova, J.; Kryštof, V.; Hamal, P.; Zbořil, R.; Kvitek, L. Antifungal activity of silver nanoparticles against Candida spp. Biomaterials 2009, 30, 6333-6340. [CrossRef] [PubMed] 
54. Jalal, M.; Ansari, M.A.; Alzohairy, M.A.; Ali, S.G.; Khan, H.M.; Almatroudi, A.; Raees, K. Biosynthesis of silver nanoparticles from oropharyngeal Candida glabrata isolates and their antimicrobial activity against clinical strains of bacteria and fungi. Nanomaterials 2018, 8, 586. [CrossRef] [PubMed]

55. Lipovsky, A.; Nitzan, Y.; Gedanken, A.; Lubart, R. Antifungal activity of ZnO nanoparticles-The role of ROS mediated cell injury. Nanotechnology 2011, 22, 1-5. [CrossRef]

56. Zaka, M.; Hashmi, S.S.; Siddiqui, M.A.; Rahman, L.; Mushtaq, S.; Ali, H.; Hano, C.; Abbasi, B.H. Callus-mediated biosynthesis of $\mathrm{Ag}$ and $\mathrm{ZnO}$ nanoparticles using aqueous callus extract of Cannabis sativa: Their cytotoxic potential and clinical potential against human pathogenic bacteria and fungi. Green Process. Synth. 2021, 10, 569-584. [CrossRef]

57. Gómez-Ortíz, N.; de la Rosa-García, S.; González-Gómez, W.; Soria-Castro, M.; Quintana, P.; Oskam, G.; Ortega-Morales, B Antifungal coatings based on $\mathrm{Ca}(\mathrm{OH})_{2}$ mixed with $\mathrm{ZnO} / \mathrm{TiO}_{2}$ nanomaterials for protection of limestone monuments. Appl. Mater. Interfaces 2013, 5, 1556-1565. [CrossRef] [PubMed]

58. Rajeswari, V.D.; Eed, E.M.; Elfasakhany, A.; Badruddin, I.A.; Kamangar, S.; Brindhadevi, K. Green synthesis of titanium dioxide nanoparticles using Laurus nobilis (bay leaf): Antioxidant and antimicrobial activities. Appl. Nanosci. 2021, 1-8. [CrossRef]

59. Giannousi, K.; Sarafidis, G.; Mourdikoudis, S.; Pantazaki, A.; Dendrinou-Samara, C. Selective synthesis of $\mathrm{Cu}_{2} \mathrm{O}$ and $\mathrm{Cu} / \mathrm{Cu}_{2} \mathrm{O}$ NPs: Antifungal activity to yeast saccharomyces cerevisiae and DNA interaction. Inorg. Chemist. 2014, 53, 9657-9666. [CrossRef]

60. Pugazhendhi, A.; Kumar, S.S.; Manikandan, M.; Saravanan, M. Photocatalytic properties and antimicrobial efficacy of Fe doped $\mathrm{CuO}$ nanoparticles against the pathogenic bacteria and fungi. Microb. Pathog. 2018, 122, 84-89. [CrossRef]

61. Sawai, J.; Yoshikawa, T. Measurement of fungi by an indirect conductimetric assay. Lett. Appl. Microbiol. 2003, 37, 40-44. [CrossRef] [PubMed]

62. Abdel-Aziz, M.M.; Emam, T.M.; Elsherbiny, E.A. Bioactivity of magnesium oxide nanoparticles synthesized from cell filtrate of endobacterium Burkholderia rinojensis against Fusarium oxysporum. Mater. Sci. Eng. 2020, 109, 1-10. [CrossRef]

63. Maringgal, B.; Hashim, N.; Tawakkal, I.S.M.A.; Hamzah, M.H.; Mohamed, M.T.M. Biosynthesis of CaO nanoparticles using Trigona sp. Honey: Physicochemical characterization, antifungal activity, and cytotoxicity properties. J. Mater. Res. Technol. 2020, 9, 11756-11768. [CrossRef]

64. Jayaseelan, C.; Ramkumar, R.; Rahuman, A.A.; Perumal, P. Green synthesis of gold nanoparticles using seed aqueous extract of Abelmoschus esculentus and its antifungal activity. Ind. Crops Prod. 2013, 45, 423-429. [CrossRef]

65. Bhuyan, B.; Paul, A.; Paul, B.; Dhar, S.S.; Dutta, P. Paederia foetida Linn. promoted biogenic gold and silver nanoparticles: Synthesis, characterization, photocatalytic and in vitro efficacy against clinically isolated pathogens. J. Photochem. Photobiol. 2017, 173, 210-215. [CrossRef] [PubMed]

66. Jalal, M.; Ansari, M.A.; Shukla, A.K.; Ali, S.G.; Khan, H.M.; Pal, R.; Alam, J.; Cameotra, S.S. Green synthesis and antifungal activity of $\mathrm{Al}_{2} \mathrm{O}_{3}$ NPs against fluconazole-resistant Candida spp isolated from a tertiary care hospital. RSC Adv. 2016, 6, 107577-107590. [CrossRef]

67. Piroonpan, T.; Huajaikaew, E.; Katemake, P.; Pasanphan, W. Surface modification of $\mathrm{SiO}_{2}$ nanoparticles with PDMAEMA brushes and Ag nanoparticles as antifungal coatings using electron beam assisted synthesis. Mater. Chem. Phys. 2020, $253,123438$. [CrossRef]

68. Ismail, A.; Kabary, H.; Samy, A. Synthesis of $\alpha-\mathrm{Al}_{2} \mathrm{O}_{3}$ Nanoparticles from Pepsi Cans Wastes and Its Fungicidal Effect on Some Mycotoxins Producing Fungal Isolates. Res. Squar. 2021. [CrossRef]

69. Lara, H.H.; Ayala-Nuñez, N.V.; Ixtepan-Turrent, L.; Rodriguez-Padilla, C. Mode of antiviral action of silver nanoparticles against HIV-1. J. Nanobiotech. 2010, 8, 1-10. [CrossRef]

70. Baram-Pinto, D.; Shukla, S.; Perkas, N.; Gedanken, A.; Sarid, R. Inhibition of herpes simplex virus type 1 infection by silver nanoparticles capped with mercaptoethane sulfonate. Bioconjug. Chem. 2009, 20, 1497-1502. [CrossRef]

71. El-Sheekh, M.M.; Shabaan, M.T.; Hassan, L.; Morsi, H.H. Antiviral activity of algae biosynthesized silver and gold nanoparticles against Herps Simplex (HSV-1) virus in vitro using cell-line culture technique. Int. J. Environ. Health Res. 2020, 1-12. [CrossRef] [PubMed]

72. Tremiliosi, G.C.; Simoes, L.G.P.; Minozzi, D.T.; Santos, R.I.; Vilela, D.C.; Durigon, E.L.; Machado, R.R.G.; Medina, D.S.; Ribeiro, L.K.; Rosa, I.L.V.; et al. Ag nanoparticles-based antimicrobial polycotton fabrics to prevent the transmission and spread of SARS-CoV-2. BioRxiv 2020. [CrossRef]

73. Antunes Filho, S.; dos Santos, O.A.L.; dos Santos, M.S.; Backx, B.P. Exploiting nanotechnology to target viruses. J. Nanotech. Nanomater. 2020, 1, 11-15.

74. Chmielewska, S.J.; Skłodowski, K.; Depciuch, J.; Deptuła, P.; Piktel, E.; Fiedoruk, K.; Kot, P.; Paprocka, P.; Fortunka, K.; Wollny, T.; et al. Bactericidal properties of rod-, peanut-, and star-shaped gold nanoparticles coated with ceragenin CSA-131 against multidrug-resistant bacterial strains. Pharmaceutics 2021, 13, 425. [CrossRef] [PubMed]

75. Mickymaray, S. One-step synthesis of silver nanoparticles using Saudi Arabian desert seasonal plant Sisymbrium irio and antibacterial activity against multidrug-resistant bacterial strains. Biomolecules 2019, 9, 662. [CrossRef] [PubMed]

76. Hamed, S.; Emara, M.; Shawky, R.M.; El-domany, R.A.; Youssef, T. Silver nanoparticles: Antimicrobial activity, cytotoxicity, and synergism with N-acetyl cysteine. J. Basic Microbiol. 2017, 57, 659-668. [CrossRef] [PubMed]

77. Alharbi, F.A.; Alarfaj, A.A. Green synthesis of silver nanoparticles from Neurada procumbens and its antibacterial activity against multi-drug resistant microbial pathogens. J. King Saud. Univ. Sci. 2020, 32, 1346-1352. [CrossRef] 
78. Saravanan, M.; Barik, S.K.; MubarakAli, D.; Prakash, P.; Pugazhendhi, A. Synthesis of silver nanoparticles from Bacillus brevis (NCIM 2533) and their antibacterial activity against pathogenic bacteria. Microb. Pathog. 2018, 116, 221-226. [CrossRef]

79. Saeed, S.; Iqbal, A.; Ashraf, M.A. Bacterial-mediated synthesis of silver nanoparticles and their significant effect against pathogens. Environ. Sci. Pollut. Res. 2020, 27, 37347-37356. [CrossRef]

80. Ebrahim-Saraie, H.S.; Heidari, H.; Rezaei, V.; Mortazavi, S.M.J.; Motamedifar, M. Promising antibacterial effect of copper oxide nanoparticles against several multidrug resistant uropathogens. Pharm. Sci. 2018, 24, 213-218. [CrossRef]

81. Sen, S.; Sarkar, K. Effective Biocidal and Wound Healing Cogency of Biocompatible Glutathione: Citrate-Capped Copper Oxide Nanoparticles against Multidrug-Resistant Pathogenic Enterobacteria. Microb. Drug Resist. 2021, 27, 616-627. [CrossRef]

82. El-Sayyad, G.S.; El-Bastawisy, H.S.; Gobara, M.; El-Batal, A.I. Gentamicin-assisted mycogenic selenium nanoparticles synthesized under gamma irradiation for robust reluctance of resistant urinary tract infection-causing pathogens. Biol. Trace Elem. Res. 2020, 195, 323-342. [CrossRef] [PubMed]

83. Al Edhari, B.; Mashreghi, M.; Makhdoumi, A.; Darroudi, M. Antibacterial and antibiofilm efficacy of $\mathrm{Ag} \mathrm{NPs}_{2} \mathrm{Ni}_{\mathrm{NPs}}$ and $\mathrm{Al}_{2} \mathrm{O}_{3}$ NPs singly and in combination against multidrug-resistant Klebsiella pneumoniae isolates. J. Trace Elem. Med. Biol. 2021, 68, 1-13. [CrossRef]

84. Ali, S.S.; Sonbol, F.I.; Sun, J.; Hussein, M.A.; Hafez, A.E.E.; Abdelkarim, E.A.; Kornaros, M.; Ali, A.; Azab, M. Molecular characterization of virulence and drug resistance genes-producing Escherichia coli isolated from chicken meat: Metal oxide nanoparticles as novel antibacterial agents. Microb. Pathog. 2020, 143, 104164. [CrossRef] [PubMed]

85. Ali, S.S.; Moawad, M.S.; Hussein, M.A.; Azab, M.; Abdelkarim, E.A.; Badr, A.; Sun, J.; Khalil, M. Efficacy of metal oxide nanoparticles as novel antimicrobial agents against multi-drug and multi-virulent Staphylococcus aureus isolates from retail raw chicken meat and giblets. Int. J. Food Microbiol. 2021, 344. [CrossRef] [PubMed]

86. Bellio, P.; Luzi, C.; Mancini, A.; Cracchiolo, S.; Passacantando, M.; di Pietro, L.; Perilli, M.; Amicosante, G.; Santucci, S.; Celenza, G. Cerium oxide nanoparticles as potential antibiotic adjuvant. Effects of $\mathrm{CeO}_{2}$ nanoparticles on bacterial outer membrane permeability. Biochim. Biophys. Acta Biomembr. 2018, 1860, 2428-2435. [CrossRef] [PubMed]

87. Ullah, S.; Khan, S.S.; Ren, Y.; Zhang, X.; Qin, M.; Xiong, X.; Krastev, R.; Jan, A.U.; Liu, L.; Yuan, Q. Near-infrared laser 808-nm excitable palladium nano-dots loaded on graphene oxide hybrid for the antibacterial activity. Appl. Organomet. Chem. 2021, 35, 1-11. [CrossRef]

88. Ling, Y.; Luo, Y.; Luo, J.; Wang, X.; Sun, R. Novel antibacterial paper based on quaternized carboxymethyl chitosan/organic montmorillonite/Ag NP nanocomposites. Ind. Crops Prod. 2013, 51, 470-479. [CrossRef]

89. Chai, W.; Zakrzewski, S.S.; Günzel, D.; Pieper, R.; Wang, Z.; Twardziok, S.; Janczyk, P.; Osterrieder, N.; Burwinkel, M. High-dose dietary zinc oxide mitigates infection with transmissible gastroenteritis virus in piglets. BMC Vet. Res. 2014, 10, 1-10. [CrossRef]

90. Qi, H.; Shan, P.; Wang, Y.; Li, P.; Wang, K.; Yang, L. Nanomedicines for the Efficient Treatment of Intracellular Bacteria: The "ART" Principle. Front. Chem. 2021, 9, 1-9. [CrossRef] [PubMed]

91. Dong, Y.; Wu, X.; Chen, X.; Zhou, P.; Xu, F.; Liang, W. Nanotechnology shaping stem cell therapy: Recent advances, application, challenges, and future outlook. Biomed. Pharmacother. 2021, 137, 1-9. [CrossRef] [PubMed]

92. Bahadar, H.; Maqbool, F.; Niaz, K.; Abdollahi, M. Toxicity of nanoparticles and an overview of current experimental models. Iran. Biomed. J. 2016, 20, 1. [PubMed] 